Article

\title{
Immigration and Multiculturalism in Italy: The Religious Experience of the Peruvian Community in the Eternal City
}

\section{Verónica Roldán}

Department Scienze della Formazione, Università Roma Tre, 00185 Rome, Italy; veronica.roldan@uniroma3.it

Received: 5 July 2019; Accepted: 8 August 2019; Published: 14 August 2019

\begin{abstract}
The present study on the religious experience of the Peruvian community in Rome belongs to the area of studies on immigration, multiculturalism, and religion in Italy. In this article, I analyze the devotion of the Peruvian community in Rome to "the Lord of Miracles". This pious tradition, which venerates the image of Christ crucified-painted by an Angolan slave-began in 1651 in Lima, during the Viceroyalty of Peru. Today, the sacred image is venerated in countries all over the world that host Peruvian immigrant communities that have set up branches of the Confraternity of the Lord of Miracles. I examine, in particular, the cult of el Señor de los Milagros in Rome in terms of Peruvian popular religiosity and national identity experienced within a transnational context. This essay serves two purposes: The first is to analyze the significance that this religious experience acquires in a foreign environment while maintaining links with its country of origin and its cultural traditions in a multilocal environment. The second aim is to examine the integration of the Peruvian community into Italian society, beginning with religious practice, in this case Roman Catholicism. This kind of religiosity seems not only to favor the encounter between the two cultures but also to render Italian Roman Catholicism multicultural.
\end{abstract}

Keywords: immigration; Peru; popular religion; the Lord of Miracles; multiculturalism; Rome

\section{Introduction}

The present study regarding the religious experience of the Peruvian community in Rome is part of a series of studies on immigration, multiculturalism, and religion in Italy.

The Italian socio-cultural context, which in recent centuries has been characterized by a traditional form of religious homogeneity, is far more variegated today. The phenomenon of migration has had an important impact upon the country's social reality, which is becoming increasingly more complex and multidimensional.

In recent decades, in fact, globalization has led to an expansion, deepening, and rapid growth of international interconnections involving every aspect of contemporary social life, including human mobility.

In the specific case of Italy, from the 1970s on, the phenomenon of migration has acquired enormous strength. Unlike in the past, Italy-along with other southern European countries, such as Spain, Greece, and Portugal-has ceased to be a land of emigration and/or transit and has become one that receives and hosts immigrants from different areas of the globe. It is within this novel process that the Eternal City finds itself once more, in the course of its millenary history, acting as host to multiple expressions of culture and religion.

Much has been written in recent years about globalization and its implications for the fields of economy, politics, and demography, among others. Studies regarding this topic have also highlighted the dimensions of the "challenge" that immigration represents, both with respect to the different actors 
involved in the process of mobility—-migrants, their families, their social networks, and their native and host communities-and the consequences to the different social fields wherein this process takes place. Human mobility involves a complex mesh of ties that reaches beyond borders, influencing the societies of the countries of origin and reshaping the identity of the immigrants themselves as well as those of the countries that receive them (Ambrosini 2107, 2014; Castles 2009).

The goal of adequate integration into different spheres of social life-and not only that of the labor market (the services in particular) - and the dream of a peaceful coexistence between different cultures and ethnic groups have long informed a lively political debate. In many cases, governments have endeavored to identify political programs for the social inclusion of legally established foreign citizens. In the mid-1990s, the project of a multicultural society seemed to find unanimous support in the West. During the second decade of the 2000s, however, a similar project seems to have come up against the hard wall of the fears of those who hold that the values of liberal democracy may be threatened by other cultures that are incompatible with traditional Western principles, such as freedom and equality. Ethnic and cultural tensions caused by multiculturalism are not wanting; yet, it is clear that the affirmation of cultural diversity is an inescapable, factual aspect of present-day societies (Castles 2009).

Today, although it is common to preach the free movement of capital, goods, products of the media, and ideas, in some European countries ruled by right-wing governments, including Italy, there is a tendency to think that borders should remain closed against those who move from south to north within the dramatic geography of global inequality (Melidoro 2015). Old Europe is experiencing a new season as the epicenter of a radical migration of peoples who come mainly from the east and south of the world in search of a better life or simply to escape hunger, war, and death and regain a dignified way of life (Vigna and Zamagni 2002; Ambrosini 2008, 2011).

In the midst of the numerous issues regarding international migration at the center of today's social science research, in this essay, I will focus on a specific aspect that is, the issue of culture and religion among immigrants. This is an area of study that is in vogue at the moment due to the growing interest it has aroused in the fields of the sociology of migration and of religion.

\section{Migration, Culture, and Religion in Italy: The Results}

\subsection{Transformations of Italian Society}

Here, I present the results of a study begun more than a decade ago regarding the phenomenon of migration in Italy and various cultural and religious issues concerning immigrants. The research began in 2007 as part of a broader study, titled Trasformazioni della Società Italiana, (Transformations of Italian Society) carried out on behalf of the Istituto di Ricerca sulla Popolazione e delle Politiche Sociali (the Institute for Research on Population and Social Policies-IRPPS) of the Italian National Research Council (CNR).

The two main questions that informed the study were as follows:

- In what sense is the phenomenon of immigration in Italy significant when analyzing the transformations that the Italian population has undergone in recent decades?

- To what extent is it useful to consider the cultural and religious aspects of immigrants when it comes to their integration with the Italian population in general?

In this essay, with the aim of providing a brief account of the Italian socio-religious reality, the following third question has been added:

- To what extent has the presence of communities of foreign citizens produced consequences regarding the complexity and plurality of the religious dimension within the Italian society of today?

The first question finds some preliminary answers in the fact that Italy is the European country with the highest growth percentage for regular foreign citizens. When we examine the data for the past 
ten years, we find a constant increase in percentages: at the end of 2010, the foreign citizens residing in Italy accounted for $7.5 \%$ of the country's total population (they numbered $6 \%$ in $2006,6.7 \%$ in 2007 , and $7.2 \%$ in 2008), whereas the average for the European Union was $6.5 \%$. The latest data, published by the Italian National Statistics Institute for 2018, report that there are 5,144,440 foreigners residing in Italy, equal to $8.5 \%$ of the total population (an incidence higher than the European Union average, which was $7.5 \%$ ).

Today, human mobility is not simply a temporary functional movement responding to the demands of the labor market and/or to a need for labor, as was the case, for example, in some European countries (England, Germany, and France) during the post-war years. Unlike in the past, migration nowadays involves the settlement of people with cultural and religious backgrounds of their own, socialized in different historical-social contexts that they are not easily willing to renounce. Moreover, today, immigration does not require those who move from one country to another to cut off their ties with their communities of origin. Maintaining relationships with the family unit-and with its consequent cultural reference-is facilitated by the development of telecommunications and the affordable cost of international transportation. Not only that, with time-work placement first and social inclusion later-immigrants not only seek to maintain a supportive relationship with their families who live at a distance but also try to bring them along, thus confirming their intention to settle definitively in the new country. Studies in Italy have revealed a growing tendency of immigrant communities to settle in the new country definitively. The indicators of stability are the formation of a family, the birth of children (14.7\% of children born in Italy have foreign parents ${ }^{1}$; they accounted for $9 \%$ in 2012), and the enrollment of children in schools (over 800,000 in Italy, equal to $9.4 \%$ of the entire school population ${ }^{2}$; 700,000 in 2012). Other indicators are the opening of bank accounts, the purchase of real-estate property, and, in some cases, the creation of businesses (Roldán 2012).

The answer to the other question posed above is that in Italy the phenomenon of migration is also associated with processes of differentiation within the sphere of religion. In fact, the country's multireligious presence has had an impact on the formation of an increasingly diversified religious pluralism. According to the statistics of the Encyclopedia of Religions in Italy (Introvigne et al. 2001), in 2000, Italians claiming membership in non-Catholic religions constituted $1.9 \%$ of the total population, but the percentage rose to $3.5 \%$ if foreigners, both legal and illegal, were included.

After more than a decade, the data revealed that the sector of the population ( $2.5 \%$ of the whole) that claims a religious identity different from Roman Catholicism accounts for 1,417,000 out of a total of 60,820,764 residents. These data are from 2012 and show that the percentage of members of non-Catholic religions in Italy - taking Italians and foreigners together-has doubled and accounts for 7.2\% of the entire population (Introvigne and Zoccatelli 2013).

According to the most recent data on demography, released in 2018 by the National Statistics Institute, Italy's total resident population stands at 60,483,973. The Italian citizens belonging to religious minorities number $2,045,900$, equal to $3.7 \%$ of the whole. If, on the other hand, foreigners are also considered, then the percentage of members of non-Catholic religions rises to over $10 \%{ }^{3}$.

It follows that immigration has, in fact, had a significant impact upon national religious pluralism, because it contributes to the acceleration of the process of religious diversification. In short, highlighting only the most numerous religious groups, the $3.7 \%$ of Italian citizens belonging to religious minorities may be subdivided as shown in Table 1.

With respect to foreign citizens who are legal residents in Italy, in 2018, their number was estimated at 5,333,000 (2018 Statistical Dossier on Immigration), with an incidence of $8.8 \%$ in this case.

1 https://www.istat.it/it/archivio/224393 (accessed on 14 June 2019); https://www.avvenire.it/attualita/pagine/senza-i-figlidegli-immigrati-inverno-demografico-pi-rigido (accessed on 14 June 2019).

2 http://www.camera.it/temiap/documentazione/temi/pdf/1112886.pdf (accessed on 14 June 2019).

3 https://cesnur.com/il-pluralismo-religioso-italiano-nel-contesto-postmoderno-2/ (accessed on 17 June 2019). 
It is evident that the phenomenon of human mobility creates new spaces for forms of religiosity, sometimes very different from one another, leading to consequent pluralization and formation of multicultural and multireligious socio-religious environments.

Table 1. Religious minorities among Italian citizens.

\begin{tabular}{ccc}
\hline Religious Minorities & Absolute Numbers & Percentages \\
\hline Orthodox Christians & 306,700 & $15.0 \%$ \\
Protestants & 476,400 & $23.3 \%$ \\
Jehovah's Witnesses (and analogous) & 411,600 & $20.1 \%$ \\
Muslims & 405,300 & $19.8 \%$ \\
Buddhists & 186,600 & $9.1 \%$ \\
Other minority religions & 259,300 & $12.7 \%$ \\
\hline Total & $2,045,900$ & $100 \%$
\end{tabular}

Source: CESNUR 2018 figures (https://cesnur.com/il-pluralismo-religioso-italiano-nel-contesto-postmoderno-2/).

This essay focuses on the immigrant community from Peru. This is the largest Latin American community at the national level in Italy. Its religious affiliation corresponds to the second group presented in Table 2-that is, the Roman Catholic community. In particular, the devotion of this group to El Señor de los Milagros (the Lord of Miracles) is analyzed here in terms of popular religiosity and national identity experienced in a transnational context.

Table 2. The religious membership of immigrants.

\begin{tabular}{ccc}
\hline Religions & Absolute Numbers & Percentages \\
\hline Orthodox Christians & $1,523,300$ & $29.6 \%$ \\
Roman Catholics & 918,100 & $17.8 \%$ \\
Protestants & 224,400 & $4.4 \%$ \\
Other Christian denominations & 39,900 & $0.8 \%$ \\
Muslims & $1,682,600$ & $32.7 \%$ \\
Other minority religions & 755,700 & $0.7 \%$ \\
\hline Total & $5,144,000$ & $100 \%$
\end{tabular}

Source: Dossier Statistico Immigrazione 2018-CESNUR 2019, figures (https://cesnur.com/il-pluralismo-religiosoitaliano-nel-contesto-postmoderno-2/).

This pious tradition, which venerates the image of Christ crucified-painted by a slave of Angolan origin in 1651-began in the outskirts of the city of Lima during the Viceroyalty of Peru. Today, the image is revered all over the world, wherever a community of Peruvian immigrants resides and has created a Confraternity of the Lord of Miracles.

In this essay, I have two aims: The first is to understand the meaning of this cult in the Peruvian community by examining the religious values and national folk traditions as practiced in a multilocality context- - that is, the value acquired by the practice of religion in a foreign context, starting with the maintenance of ties with the homeland and the production of new meanings of identity as experienced within multifaceted communities and networks. The second is to examine the integration of the Peruvian community into Italian society, beginning with religious practice, in this case Roman Catholic. This kind of religiosity seems not only to favor the encounter between the two cultures but also to render Italian Roman Catholicism multicultural ${ }^{4}$.

4 In recent years, a number of different studies by Italian scholars have been dedicated to investigating the role of cultural (and religious) mediation carried out by the Christian Churches in Italy, including the Roman Catholic Church, with respect to religious communities formed by foreign people (Ambrosini et al. 2019, 2019; Giuseppe et al. 2018; Pace and Giordan 2015; Buonasorte 2011; Brambilla and Rizzi 2011; Berzano et al. 2010; to mention just a few). 


\subsection{The Presence of the Peruvian Community in Rome}

According to the Statistical Dossier on Immigration (IDOS 2018), in 2018, the Peruvian community was the largest of the groups of immigrants hailing from Latin America, with a presence in Italy of 97,379 residents, of whom 56,667 (58.2\%) were women. The second largest Latin American community was that of Ecuador, with 80,377 residents, of whom 45,887 (57.1\%) were female. The majority of these two communities are members of the Roman Catholic Church.

At a national level, the Peruvian legal residents in the country number 91,969 (of whom $58.8 \%$ are women), and they have various types of residence permits: $49.6 \%$ for work, $46.9 \%$ for family reasons (IDOS 2018).

Although these two Latin American countries are not included in the rankings of the most numerous immigrant communities on a national scale in Italy, as are the immigrant communities of Romania, Albania, Morocco, China, and the Ukraine, the Peruvian immigrant community ranks ninth in terms of size in the Lazio region - the capital of which is Rome-after immigrant communities from Romania, the Philippines, Bangladesh, India, China, the Ukraine, Albania, and Poland.

The Italian capital is characterized by a strong foreign female presence, a plurality of nationalities of origin, an increase in family reunifications, a substantial presence of people from Eastern European countries, a diversification of productive activities in the tertiary sector, and an increase in small businesses (IDOS 2018).

With respect to the integration of immigrants within the area of employment, we need to consider an important feature of the Italian labor market, namely, the existence of informal economies having no equal within the European Union (Zanfrini 2000; Ambrosini 2103; Ambrosini 2001). This factor, together with the aging of the Italian population, is decisive for the assimilation of immigrants into the services sector, developing a vast labor submarket. However, it must be noted that the new Italian government, which assumed office in June 2018, has made the rules for the entry of new immigrants and the employment of foreign workers (one of the phenomena characterizing the Italian labor market in recent decades) more stringent $t^{5}$.

\section{The Cultural and Religious Aspect of Immigration in a Context of Transnationalization}

In the aforementioned research project regarding immigration and inclusion in Rome, religion was already shown to be an effective, though not actually essential, means of integration, first within the community of fellow ex-patriots and later within Roman society, as was the case, for example, with the Latin American, Philippine, and Ukrainian communities, among others (Roldán 2012).

Today, we can refer to the work of Mexican scholars Renée de la Torre and Patricia Arias (De la Torre and Arias 2017), Religiosidades trasplantadas (Transplanted religiousness) with regard to this issue.

Migration generates the need to reunify the time-space links between two homes: that of the origins and that of destination. What has been left behind and what has been encountered. And it is here that religion becomes an important resource for migrants, a resource for linking scattered territories, multicultural identities, networks of friends and relatives dispersed in space, connecting memories with experiences of the present and utopias. (De la Torre and Arias 2017, p. 18)

In keeping with studies in this field of research, it has been observed that, although immigrants do not always practice their religion in their countries of origin, they often begin to do so, at times even frequently, in their host countries. This is a phenomenon that also plays a fundamental role when seeking to satisfy the need to plant new roots. In many cases, the religious community becomes

5 Cfr. Ottavo Rapporto annuale 2018 “Gli stranieri nel mercato del lavoro in Italia”. http://www.lavoro.gov.it/notizie/Pagine/ Ottavo-Rapporto-annuale-Gli-stranieri-nel-mercato-del-lavoro-in-Italia.aspx (accessed on 21 June 2019). 
a valid means of social participation, solidarity, and group identity. As a result, religious practice is resumed, and other dimensions of religiosity—belief, religious experience, and affiliation-are given new life (De la Torre and Arias 2017; De la Torre and Gutiérrez Zuñiga 2017; Oro et al. 2012; Segato 2007; Odgers 2008).

From this perspective, religious events are seen as cultural assets to be adapted to the new situations arising from the migratory experience. Therefore, multilocal networks and binational or multinational communities are created and lead to a reformulation of cultural and religious identities. To better delineate the characteristics of transnationalization it may prove useful to refer to the scheme outlined by Renée de la Torre, this time writing with Cristina Gutiérrez Zúñiga (De la Torre and Gutiérrez Zuñiga 2017) in the work Mismos pasos y nuevos caminos. Transnacionalización de la danza conchero azteca. Here, transnationalization is defined as the product of various phenomena that generate flows of cultural materials and goods that reach beyond national and natural boundaries. Yet, to understand the effects of this process, it does not suffice simply to observe-as is the norm-two of its elements: de-contextualization and portability. It is also necessary to consider the following three phases of the process, namely de-territorialization, trans-territorialization, and re-territorialization. These concepts are discussed in detail below:

- De-territorialization takes place when, at first, religious beliefs, popular rites, and national folklore emblems, go beyond the cultural contexts and traditional anchorages to which they belonged and where they were experienced. They are reproduced by the dynamics of the transmission of knowledge and inherited through rites of initiation, with the rules and knowledge being regulated by institutions (by means of the priesthood or theological studies) and/or upheld by a cultural community. These traditional supports monitor the rules and norms of practice and determine, availing themselves of sanctions, the roles to be played within the community. On the other hand, the significance of such practices is safeguarded by shared conventions. When symbolic systems are de-territorialized (delocalized), they lose their regulatory supports. As a result, the symbols, ideas, practices, specialized agents, knowledge, and goods charged with memory and identity are uprooted.

- Trans-territorialization is the transformation of religious beliefs into "movable, transportable goods", removed from their original territories and traditions and made to circulate through new circuits and new distribution networks. Generally speaking, this second phase is produced by flows of travel, migration, tourism, the media, and social networks, as well as by the global commodification of cultural heritages. The global trans-territorialization of cultural heritage causes its removal and consequent independence from traditional authentication procedures and the ideological, regulatory, moral, and structural burdens and duties of the traditional institutions and/or communities.

- Re-territorialization involves not only the staging of rituals in new contexts but also their cultural and political reintegration, in addition to their adaptation to new cultural norms. This process causes their reorganization within a different national context, making them emblematic of particular social segments within the community and subjecting them to resignification within new contents of relevance at the local level. Vice versa, this process re-symbolizes some of the original contents on the basis of local materials and lexicon (Segato 2007, p. 185). This dynamic is capable of generating hybrid versions of imported goods (the juxtaposition of meanings between the culture of origin and that of the destination), as well as a re-semantization favoring the recovery and enhancement of those cultural and ethnic traditions within a newly-adopted socio-cultural context (De la Torre and Gutiérrez Zuñiga 2017, pp. 42-43).

In fact, the re-territorialization of religious experiences within a different context can lead to the recuperation and relaunching of ancestral traditions (Durand 2003; Platt 2006). This is the case for the cult of the Lord of Miracles practiced by the Peruvian community in Italy. 


\section{Devotion to the Lord of Miracles in Rome}

\subsection{The Historical Origins}

Today, at the end of the second decade of the third millennium, the religious feast celebrated by the Peruvian community living in Rome is a living expression of its devotion to its national patron, el Señor de los Milagros [the Lord of Miracles] in a transnational context.

Its historical origins date back to the 17th century and to the City of the Kings, as Lima was called during of the Viceroyalty of Peru.

It should be noted that the story of this cult of Christ Crucified itself contains elements of a global dynamic. It is, in fact, the result of the encounter between three communities from three different continents-America, Africa, and Europe-in the persons of the indigenous Indians, whom we call today the "native peoples", the African slaves, and the Spanish colonizers.

According to legend, the cult was born around 1651 among the African slaves of the Pachacamilla district, which was founded in the outskirts of Lima by Francisco Pizarro in 1535. It is a syncretic cult, the result of a merger between Roman Catholic evangelization by the Spanish conquistadores and pre-Hispanic influences from a cult perpetuated by the indigenous population and dedicated to the god Pachacamac.

Peruvian anthropologist María Rostworowski (2015), an expert on issues of indigenous history, emphasizes the fact that, initially, the veneration of the Lord of Miracles favored the aggregation of two marginalized ethnic groups living in Lima: the African slaves and the Indians of Pachacamac, a coastal area near the capital.

According to popular belief, three episodes rendered the image of the crucified Christ-painted by an Angolan slave on a makeshift adobe wall-miraculous: the picture's supernatural resistance to obliteration by the religious authorities of the time, who refused to accept this cult of Afro-cultural origin, because it was too "cheerful", "colorful", "musical", and "corporeal"; its survival despite a terrible earthquake that destroyed the city of Lima in 1655; and its role in the miraculous recovery, in 1670, of Antonio León, who suffered from an incurable disease.

The fame of the miraculous image spread gradually to different areas of the city. Toward the end of 1680, a Spanish devotee, Sebastián de Antuñano, had a copy of the image painted on canvas so that it might be carried through various districts of the city and bless its inhabitants, especially the most disadvantaged, the sick, and convicts. Over time, devotion spread to the whole of the Viceroyalty and remained alive for centuries. Indeed, on 12 May 2010, the Lord of Miracles was declared the "Patron of Peruvian Catholic Religiosity and Spirituality". Nowadays, the procession held in his honor is the largest Roman Catholic Christological procession held in Latin America. One of the salient and distinguishing features of this cult is the fact that it focuses, exceptionally, on the figure of Christ. This distinguishes it radically from most of the devotional practices of Latin America, which tend to be centered on the figure of the Blessed Virgin. Among the numerous examples of this kind of veneration, we have the Virgin of Guadalupe in Mexico, the Madonna of the Angels in Costa Rica, the Virgin of Chiquinquirá in Colombia, Our Lady of Charity of Cobre in Cuba, the Virgin of Quito in Ecuador, and the Virgin of Luján in Argentina (Roldán 2017, 2018b).

Today, the two processions accompanying the image of the Lord of Miracles that take place in Lima during the month of October-the salida (exit) of the image and the vuelta (the return) to the Basilica de las Nazarenas, where the original painting is kept-bring millions of the faithful flocking to the streets of the city.

The image of the Lord of Miracles is also venerated in every foreign city where there is a community of Peruvian immigrants who have formed a Confraternity of the Lord of Miracles, following the original model of that in Lima.

The Confraternity of the Lord of Miracles in Rome is considered to be the most significant of those established abroad because of the symbolic value of its presence in the Eternal City and the closeness of the Pope as the successor of St. Peter. In an interview released for a documentary regarding the 
procession in Rome, produced in $2014^{6}$ (Roldán 2015), the priest responsible for the Latin American communities of the Diocese of Rome, Father Luis Hernán Olivos Aguilar, summed up the religious sentiment and cultural identity surrounding this expression of national devotion by citing the popular axiom: "Where there is a Peruvian, there is also the Lord of Miracles".

In fact, the Confraternities for the veneration of the image of the "purple Christ" - so called because of the color of the clothes the members of the Confraternity wear-are present in hundreds of countries, such as Argentina, Brazil, Canada, France, Japan, Italy, Spain, the United States, Mexico, and Switzerland, among others.

Confirming the unbreakable bond existing between the Lord of Miracles and his people-even those traveling and residing abroad—on 15 October 2005, this patron saint of Peru was proclaimed the "Protector of Peruvians", at home or abroad.

\subsection{The Cult in Rome}

With respect to the origins of this devotional practice in Rome specifically, the collective memory claims different moments when, and places where, this form of community worship among Peruvian immigrants began. The most widespread version is that which recalls a devout Peruvian who-having recovered from a serious illness by grace she received from the national patron—brought a small image of the Lord of Miracles from Lima and asked the permission of the parish priest of the Basilica of Santa Maria degli Angeli ${ }^{7}$ to hold a procession in the churchyard. Today, members of la Hermandad del Señor de los Milagros de Roma (HSMR) remember this woman in their masses and prayers, believing that she played a fundamental role in promoting the cult and in founding the Roman branch of the Confraternity.

According to Peruvian anthropologist and professor at Rome's Gregorian University, Carlos M. Salazar (2003), there are other stories of religious cults born in the early 1990s in different parts of the Eternal City, particularly among Peruvian immigrants who found themselves in difficult situations and, in some cases, even beyond the limits of legality. At that time, meetings involving the sacred image were held in the parish of Santa Lucia, in the Prati district of Rome - not far from the Vatican-and also in the state prison of Rebibbia, on the outskirts of the city. According to this scholar, the Confraternity of the Lord of Miracles in Rome was set up in 1992 and was supported by the Latin American Center "Tra noi" (Among us), an association that seeks to promote the acceptance and Christian integration of foreigners in Italy.

As happens in other smaller cities and towns, both in Italy and in other countries, the current image of the Lord of Miracles of Rome is a replica of the original. For several years now, the image in Rome has been housed in one of the side chapels close to the main altar of the church of Santa Maria della Luce in Trastevere. This parish is also the seat of the "Latin American Mission" of the Diocese of Rome, founded in 2000 by the Scalabrinians to cater to 18 communities from different Latin American countries, speaking both Spanish and Portuguese.

As to the main religious festival, Rome's Peruvian community organizes two processions yearly during the month of October. These represent two momentous, collective, religious occasions for thousands of Peruvians, not only for those living in the capital but also for those living elsewhere in Italy. These Peruvians travel to Rome to take part mainly in the second procession, which winds its way through the streets of the city center to arrive at the Vatican. The festival ends with the Pontiff's Angelus and a mass of thanksgiving in Saint Peter's Basilica. At the end of the Eucharistic celebration, the sacred image is brought back to the church of Santa Maria della Luce, where it remains at the disposal of devotees for the rest of the year-that is, until the processions of the following October (Roldán 2018a).

6 See details in Supplementary Materials: https://www.youtube.com/watch?v=9LP3gwHdZrI.

7 At that time, the association for assistance to Latin American immigrants had its offices in the premises of that basilica. 


\subsection{The Peruvian Community and Its Integration into the City of Rome}

As the aforementioned study of religion and social inclusion in Rome (Roldán 2012) revealed, religion may act as a possible channel favoring integration. With respect to the inclusion of the Peruvian community, particularly in the Diocese of Rome, the feast of the Lord of Miracles undoubtedly represents an emblematic case. The first significant moment is the first procession-the salida or exit of the image of the Lord of the Miracles from the church in Trastevere where it is normally housed and its transfer, on a lorry, to the Basilica of Santa Maria degli Angeli from where the procession begins its journey through the streets of the capital, assisted by the municipal police, who divert traffic as the procession passes.

This image, which was venerated, initially, only by the most marginalized sectors of the European and Christian society transplanted in the new continent, is, today, not only the Catholic symbol par excellence of an entire nation but is also acknowledged and legitimized by the universal headquarters of Catholicism.

The symbolic significance of the procession is of great importance if we consider that this replica of the sacred image of the crucified Christ (painted by an African slave-the last link in the chain of the Catholic society of the Spanish conquerors in the Americas in the 17th century-on the adobe wall of a hut destined for slaves in the outskirts of the City of Kings), today, after almost four centuries, passes through the streets of the city that hosts the Holy See, whose visible head is the successor of St. Peter, the Pontifex Maximus (Supreme Pontiff) of the Church created by Jesus Christ himself (Matthew 16, 13-28).

In support of the recognition and acceptance of this foreign presence by the city of Rome, its diocese, and the Vatican, the two processions in honor of the Cristo Moreno involve two of the city's and the Church's most important cathedrals: that of the Pope as the Bishop of Rome-the Basilica of Saint John in the Lateran - and that of the universal seat of Catholicism, the Vatican-Saint Peter's Basilica. Along the route of the salida (exit), the image also passes in front of the Basilica of Saint Mary Major, and after a slow procession lasting several hours, accompanied by singing, prayers, and folk dances-and some pauses to taste typical Peruvian food or drink-it arrives at the Basilica of Saint John in the Lateran, the cathedral of the city of Rome, where it remains for two weeks to be venerated until the second procession.

The second procession, called la vuelta (the return), generally takes place on the last Sunday of October, when the image is transferred to the Chiesa Nuova, in the city's historic center. On this occasion, as well, the procession is preceded by religious and folkloristic tributes and features most of the Peruvian Confraternities present in Italy and, at times, those from other European countries, such as Spain and France.

At the end of the second procession, after passing through the center of Rome, the Peruvian community carries the image of the Lord of Miracles in a solemn, penitent procession to the Vatican to participate in the Pope's Angelus and in a mass of thanksgiving in Saint Pater's Basilica.

Father Olivos Aguilar, the priest responsible for the Latin American communities in Rome, explained that the two processions have maintained the purpose that they have had since the beginning of the cult in 1680-that of bringing the Lord to "an encounter with his people", passing through the streets and blessing its inhabitants. The reaction of the Romans to this spectacular ethnic-religious manifestation in the public area is largely one of curiosity and acceptance.

The image, similar to that in Lima, is transported in las sagradas andas-that is, a canopy composed of a silver arch framing the image of the crucified Christ and the Virgin of the Clouds behind it. It is decorated in the same way as that in Lima, with golden rays of light, angels, silver vases, and other details. The creation of the replica itself required the collaboration of the hosted and hosting communities, the Peruvians and the Italians, respectively. In fact, the creation of the canopy was achieved in two years thanks to the economic contribution of the Peruvian faithful and the work of qualified Italian artists, experts in religious art. 
As it is housed by the parish that caters to all the Latin American communities, the Roman Confraternity is also international in character, as it cohabits with members of the faithful from other Latin American countries, as well as with Italians and immigrants from Eastern Europe. In a letter, priest Luis Pérez Godoy wrote the following: "The Confraternity wishes to generate a movement of unity between Latin Americans and an attitude of gratitude towards Rome, the city that hosts them. It also wishes to act as an instrument of re-evangelization and an invitation to the Italians themselves to rediscover Christian fervor through the Confraternity".

Finally, a significant element that needs to be emphasized is the fact that the Confraternity of the Lord of Miracles is a member of the confraternities of the Vicariate of Rome and is considered the most numerous of the foreign confraternities ${ }^{8}$. Structurally, it adheres to the original model of that in Lima: it consists of four groups of men, called cuadrillas de hombres cargadores (in Lima, they number twenty), who load the canopy onto their shoulders, and a group of women, called sahumadoras, who carry incense during the processions, praying and singing. The Confraternity is presided over by a Mayordomo and a Vice Mayordomo, followed by a general leader. The women also have a leader called la Mayorala.

\subsection{The Religiosity and Living of the Peruvian Tradition Abroad}

The devotion of the Confraternity of the Lord of Miracles and of the entire Peruvian community in Rome is characterized by a religious sentiment, the highlight of which is the feast of the patron held in October. Meetings of this community continue, however, throughout the year, particularly in the parish of Santa Maria della Luce in Trastevere. Moreover, it is thanks to the experience of such religious practices that the members of the community keep their culture of origin alive over time and space. It is within this community and religious environment that the Peruvian immigrants in Rome renew their identity, the memory and traditions of their people, their music, their songs, their dance (especially la marinera norteña), their typical costumes, and their food and, above all, share their religious experience with their "brothers" - all children of the same distant land. Thus, they experience their own culture and religion in transnational and multicultural contexts, where their roots are now not only set and transplanted but also re-signified and lived. The chaplain of the Latin American community of the Diocese of Rome, Father Olivos Aguilar, pointed out that the devotion to the Lord of Miracles features a marked presence of the new generations, a sign of the perpetuation of the cultural tradition: "In the Confraternity of Rome, many children and young people participate, to carry on the tradition handed down by their grandparents, their parents, their family and they do so with great devotion" (Roldán 2015). Indeed, the veneration of the holy image of Christ may be interpreted not only as a manifestation of faith but also as an element of identity and closeness to the tradition and culture of the country of origin and as a legacy to be handed down to future generations, especially those living far from the homeland.

8 Another example of the Roman Catholic Church's role as a cultural mediator in Italy with respect to the integration of foreigners and the local community is provided by today's 75\% Roman Catholic, 150,000-strong Sinhalese community, which has been present in Italy for over 30 years. In this case, the fact that the cult's practices are associated with Italian saints, St. Anthony of Padua and St. Rosalia of Palermo, is particularly interesting. To celebrate St. Anthony, thousands of immigrant pilgrims from Sri Lanka have been meeting for years on 1 May in the Basilica of Saint Anthony of Padua to continue a cult born in their native land. In 1500, Portuguese missionaries introduced St. Anthony to the inhabitants of Sri Lanka, who gladly adopted the saint. Today, in Padua, the Sri Lankan community celebrates him with prayers, songs, dance, and traditional costumes, as well as by decking the main altar of the Basilica with flowers. In Palermo, an equally colorful celebration is held in honor of St. Rosalia in September and is welcomed by the local population. All told, even in the case of this community, the Roman Catholic faith, expressed through the traditions of the immigrants' country of origin, is revisited and integrated into a new context, fostering not only a meeting of the immigrant community, far away from its land of origin, but also an encounter between the immigrant community and the community of the host country. 


\section{Conclusions}

The religious experience of the Peruvian community in Rome, characterized by a high degree of religious institutionalization (due to belonging to the confraternities of the Diocese of Rome), shares with other migratory movements, the ability to recompose its culture and identity in a field characterized by transnational dynamics. As a result, migration becomes something more than a personal or family project due to a transfer from one place to another in search of better living conditions; it involves circularity, return, networking, and connections involving the personal, local, regional, national and transnational spheres, as well as the creation of multisite communities, whose members during the "diaspora" remain "connected" with their original framework of reference and belonging but in a new way.

In short, during the second half of the 20th century, international migration became one of the main factors impacting social transformation all over the world. Its importance seems to have increased even further during these first two decades of the 21st century as the mobility of people increases, bringing in its wake new social challenges. Today, in Italy, the "native" population and the foreign population are the protagonists of processes that mold society in a new manner. The considerable presence of immigrants within the country has transformed the texture and layout of cities, calling for effective policies aimed at favoring the inclusion of non-Italian residents in every area of society, not only in the economic sector of the labor market. Similarly, the sociology of migration shows that the term "integration" is a polysemic concept that may be used to indicate a variable series of processes, including a set of positions ranging from the social and cultural assimilation of foreign communities (typical of the French model of the last century) to the implementation of multicultural policies (the British model) aimed at promoting the creation of multiethnic and multicultural societies.

In the second decade of the present century, the human mobility resulting from migration has led to the formation of increasingly complex and plural societies. The new arrivals-bearers of cultures, values, and religious beliefs largely different from those of the host society—claim the right to maintain their idiosyncrasies and demand respect for their differences. However, projects of inclusion are not always linear. In many cases, they come up against the persistence of old fears regarding the social impact of immigrant populations. In Italy, the permanence of large immigrant communities has turned out to be a challenge to policymaking, often leading to negative solutions informed by opposition to the phenomenon in the form of more rigid positions regarding the reception and hosting of new arrivals.

As a result, immigrant communities are obliged to deal with two major challenges: the challenge of ensuring their own social inclusion in the host country and the challenge of maintaining their own cultures and idiosyncrasies in a foreign environment. To this end, immigrants as minorities rely on a broad variety of strategies and responses and often manage to influence the reactions and responses of the host society. This is the case of the Peruvian community in Rome, whose inclusion, as far as the cultural dimension is concerned, is facilitated by its religious affiliation. Furthermore, thanks to its devotion to the Lord of Miracles, the Peruvian community experiences its religious identity simultaneously with its country of origin and remote affective bonds.

The sociological literature regarding human mobility views the strategy of the multiplication of religious images that migrate with their devotees as a threefold process of transnationality: the preservation of roots in the countries of origin; the transfer of (sacred) images outside of native borders; and the re-territorializing of the image elsewhere (De la Torre and Arias 2017; De la Torre and Gutiérrez Zuñiga 2017).

The religiosity experienced at the same time by the different Peruvian immigrant communities around the world not only nourishes the diasporic community bonds but also creates new forms of identity, citizenship, and belonging, starting with the key identarian symbols of a pilgrim people whose shrines and celebrations are revived within the ambit of a transnational, global, and multicultural network while remaining rooted in a single multisite national spirit. 
Supplementary Materials: Video S1. El Señor de los Milagros en Roma (documentary), Verónica Roldán (2015) in collaboration with the Roberto Rossellini Foundation, Higher Technical Institute Rome. Viewable on Youtube at "Veronica Roldan-Sociologia". Original Spanish soundtrack with subtitles in English: https://www.youtube.com/ watch?v=9LP3gwHdZrI\&t=71s.

Funding: This research was funded by Istituto di Ricerca sulla Popolazione e delle Politiche Sociali-IRPP [the Institute for Research on Population and Social policies] — Consiglio Nazionale delle Ricerche—CNR [the National Research Council] and Università Roma Tre [the Roma Tre, University of Rome, Italy].

Conflicts of Interest: The author declares that there is no conflict of interest.

\section{References}

Ambrosini, Maurizio. 2001. La fatica di integrarsi. Immigrati e lavoro in Italia. Bologna: Il Mulino.

Ambrosini, Maurizio. 2008. Un'altra globalizzazione. La sfida delle migrazioni transnazionali. Bologna: Il Mulino.

Ambrosini, Maurizio. 2011. Sociologia delle migrazioni. Bologna: Il Mulino.

Ambrosini, Maurizio, ed. 2103. Irregular Migration and Invisible Welfare. London: Palgrave MacMillan.

Ambrosini, Maurizio. 2014. Migration and Transnational Commitment: Some Evidence from the Italian Case. Journal of Ethnic and Migration Studies 4: 619-37. [CrossRef]

Ambrosini, Maurizio. 2107. Migrazioni. Milan: Egea-Università Boconi.

Ambrosini, Maurizio, Naso Paolo, and Pavarati Claudio. 2019. Il dio dei migranti. Pluralismo, conflitto ed integrazione. Bologna: il Mulino.

Ambrosini, Maurizio, Paola Bonizzoni, and Molli Samuele Davide. 2019. Chiese migranti. Il cristianesimo plurale degli immigrati a Milano. Bologna: il Mulino.

Berzano, Luigi, Genova Carlo, Introvigne Massimo, Ricucci Roberta, and Zoccatelli Pierluigi. 2010. Cinesi a Torino. La crescita di un arcipegalo. Bologna: il Mulino.

Brambilla, Chiara, and Massimo Rizzi. 2011. Migrazioni e religioni. Un'esperienza locale di dialogo tra cristiani e musulmani. Milano: FrancoAngeli.

Buonasorte, Nicla. 2011. I cristiani immigrati: fratelli stranieri. Cristiani d'Italia. Enciclopedia Treccani. Available online: http://www.treccani.it/enciclopedia/i-cristiani-immigrati-fratelli-stranieri_\%28Cristiani-d\% 27Italia\%29/ (accessed on 6 August 2019).

Castles, Stephen. 2009. Le migrazioni internazionali agli inizi del ventunesimo secolo: tendenze e questioni global. In Migrazioni e società. Una rassegna di studi internazionali. Edited by Maurizio Ambrosini and Emanuela Abbatecola. Milan: FrancoAngeli.

De la Torre, Renée, and Patricia Arias. 2017. Religiosidades trasplantadas. Recomposiciones religiosas en nuevos escenarios transnacionales. Tijuana: El Colegio de la Frontera Norte.

De la Torre, Renée, and Arias Cristina Gutiérrez Zuñiga. 2017. Mismos pasos y nuevos caminos. Transnacionalizacion de la danza conchero azteca. Jalisco: El colegio de Jalisco.

Durand, Jorge. 2003. El talibán americano y la Virgen de San Juan de los Lagos. In Religión y Cultura. Edited by Miguel Hernández and Juárez Cerdi Elizabeth. Zamora: Colmich, pp. 165-80.

Giuseppe, Giordan, Ling Han, and Andrea Valzania. 2018. La chiesa cristiana cinese in Italia. Religioni e Società 91: $45-55$.

IDOS. 2018. Centro Studi e Ricerche and Confronti. In Dossier Statistico Immigrazione. Roma: IDOS.

Introvigne, Massimo, and Pierluigi Zoccatelli, eds. 2013. Enciclopedia delle religioni in Italia. Leumann: Elledici.

Introvigne, Massimo, Pierluigi Zoccatelli, Nelly Ippolito Macrina, and Verónica Roldán. 2001. Enciclopedia delle Religioni in Italia. Leumann: Elledici.

Melidoro, Domenico. 2015. Multiculturalismo. Una piccola introduzione. Roma: Luiss University Press.

Odgers, Olga. 2008. Construcción del espacio y la religión en la experiencia de movilidad. Los santos patronos como vínculos espaciales en la migración México-Estados Unidos. Migraciones Internacionales 4: 5-26.

Oro, Ari P., Carlos A. Steil, and João Rickli. 2012. Transnacionalização religiosa. Fluxos e redes. San Paulo: Tercero Nome.

Pace, Enzo, and Giuseppe Giordan. 2015. Il Pluralismo Religioso tra Autonomie Regionali e Sperimentazioni Localistiche. L'Italia e le sue Regioni. Enciclopedia Treccani. Available online: http://www.treccani.it/enciclopedia/il-pluralismo-religioso-tra-autonomie-regionali-e-sperimentazionilocalistiche_\%28L\%27Italia-e-le-sue-Regioni\%29/ (accessed on 6 August 2019). 
Platt, Mary Louise. 2006. ¿Por qué la Virgen de Zapopan fue a Los Ángeles? Algunas reflexiones sobre la movilidad y la globalidad. A Contracorriente 2: 1-33.

Roldán, Verónica. 2012. Inmigración e inclusón en Italia. El caso de la ciudad de Roma. Buenos Aires: Biblos.

Roldán, Verónica. 2015. El Señor de los Milagros en Roma. A Documentary, in Collaboration with the Roberto Rossellini Foundation, Higher Technical Institute Rome. Viewable on Youtube at "Veronica Roldan-Sociologia". Original Spanish Soundtrack with Subtitles in English. Available online: https://www.youtube.com/watch?v=9LP3gwHdZrI\&t=71s (accessed on 10 June 2019).

Roldán, Verónica. 2017. La Argentina religiosa de los años 2000. Antes y después del Papa Francesco. In Francisco. El impacto de su pontificado América Latina. Edited by Roldán Verónica and Frigerio Alejandro. Buenos Aires: Biblos, pp. 19-36.

Roldán, Verónica. 2018a. Religión e inmigración: El Señor de los Milagros en Roma. Encartes Antropológicos 1: 140-151. Available online: http://www.encartesantropologicos.mx/ (accessed on 5 May 2019).

Roldán, Verónica, ed. 2018b. Papa Francesco e il cattolicesimo sud globale. L'impatto del suo pontificato in Italia. Milan: FrancoAngeli.

Rostworowski, María. 2015. Pachacamac. Lima: Instituto de Estudios Peruanos.

Salazar, Carlos M. 2003. Medizione e affermazione identitaria: La processione dei latinoamericani a Roma. Paper presented at the AISEA-Associazione italiana di Studi Demo-Etno-Antropologici Congress, Rome, Italy.

Segato, Rita L. 2007. La nación y sus otros. Raza, etnicidad y diversidad religiosa en tiempos de Políticas de la identidad. Buenos Aires: Prometeo.

Vigna, Carmelo, and Stefano Zamagni. 2002. Multiculturalismo e identità. Milan: Vita e Pensiero.

Zanfrini, Laura. 2000. "Programmare" per competere. I fabbisogni professionali delle imprese italiane e la politica di programmazione dei flussi migratori. Milan: FrancoAngeli.

(C) 2019 by the author. Licensee MDPI, Basel, Switzerland. This article is an open access article distributed under the terms and conditions of the Creative Commons Attribution (CC BY) license (http://creativecommons.org/licenses/by/4.0/). 